\title{
Impact Of IASB \& FASB On Financial Statements
}

Veronica Paz, Nova Southeastern University, USA

Thomas Griffin, Nova Southeastern University, USA

\begin{abstract}
The purpose of this research is to determine the impact of material differences in the conceptual framework of the International Accounting Standards Board (IASB) and the Financial Accounting Standards Board (FASB) on the financial statements.
\end{abstract}

\section{INTRODUCTION}

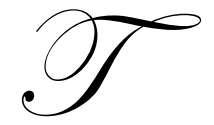

he purpose of this research is to determine what material difference in the conceptual framework of the International Accounting Standards Board (IASB) and the Financial Accounting Standards Board (FASB) has on financial statements. This research will also analyze what impact of the global conceptual framework project taken on by the IASB and FASB has on the financial statements.

The FASB issues Statements of Financial Accounting Standards (SFAS) and Statement of Financial Accounting Concepts (SFAC) to guide accountants in the preparation of financial statements using General Accepted Accounting Principles (GAAP). The purpose of GAAP is to assure financial statement users that a particular item means essentially the same thing on the financial statements of any organization doing business in any industry (Young, 1994). This translates into transparency of financial statements across countries and industries. These standards are the basic framework that the preparers of financial statements use in the generation of financial reports. These pronouncements represent GAAP and are officially recognized as authoritative by the Securities and Exchange Commission (SEC) and the American Institute of Certified Public Accountants (AICPA)("Facts About FASB," 2005). Financial statements of publicly traded companies have to be presented in accordance with GAAP and the regulations of the SEC. The International Accounting Standards Board (IASB) and Financial Accounting Standards Board (FASB) have taken on the project of a joint conceptual framework and have issued a draft on the unified conceptual framework toward the goal of one global framework.

The International Accounting Standards Board (IASB) serves as the regulatory body for all international financial statements undergo a process similar to the FASB. The equivalent to SFAS is the International Financial Reporting Standards (IFRS). The IASC concepts are issued by the IASB. The assumption is that there is a significant impact on the financial statements and this ambiguity is what is frustrating the process of preparing transparent financial statements.

The procedure used to conduct this research is to determine the differences in the IASB and FASB conceptual framework by comparing the IASB International Financial Reporting Standards (IFRS) used by Canadian publicly traded companies as compared to the United States. One of the outcomes of this study is to analyze the influence that the conceptual framework of both regulatory bodies has on the financial statements.

\section{Significance of Study}

This study, it is hoped, will unveil any possibility of misstatement or confusion from the lack of global issuance of guidelines and the complexity of the concepts issued to date and determine if the concepts are materially different in the IASB and the FASB. This examination will demonstrate what, if any, impact the lack of consistency in concepts has on the balance sheet and income statement. The FASB has strict guidelines. The complexity of the accounting concepts has preparers and users of the financial statements in a state of confusion. This confusion and 
the lack of transparency of the financial statements across countries add to the difficulty of preparing consistent financials. The current framework is more principles-based, not rules-based. The profession has taken steps to move toward principles based accounting to allow for consistency in standards in a global marketplace. This study presupposes that the concepts are too ambiguous, hence the lack of clear and concise reporting on the balance sheet and income statement in totality.

The research will illustrate that the SFAC are in need of a revisit to serve as the current fundamental building blocks of financial reporting. The IASB and FASB are currently working jointly to establish one conceptual framework long overdue by the profession. This lack of congruency and consistency leaves the financial statements in a state of disengagement. The standard setting process needs improvements to issue concepts more proactively. With the fast moving economy, rules need to be established quickly and before a complex situation arises. Regulations applied after the fact, inhibit the credibility of the accounting profession. Therefore, a global and consistent conceptual framework will add in the ability to record similar transactions consistently across industries and countries.

\section{Research Question}

The research question is to determine the impact that the IASB and FASB conceptual framework has on the financial statements.

This research problem could be subdivided into the following sub problems:

1. Determine the impact that the Statement of Financial Accounting Concepts (SFAC) has on the financial statement.

2. Determine the impact the IASB concepts have on the financial statements, both the balance sheet and income statement.

3. Determine if the conceptual framework should be more principles based as opposed to rules-based.

\section{Definition of Critical Terms}

American Institute of Certified Public Accountings (AICPA) -- "the premier national professional association in the United States" (AICPA, 2008).

Balance Sheet-- a statement that relates to a specific point in time, which reports the company's assets, liabilities and owners' equity on a specified date (Dyckman et al., 1989). The balance sheet is also referred to as the Statement of Financial Position.

Financial Accounting Standards Board (FASB) -- is the rule making body that establishes financial accounting principles (Dyckman et al., 1989).

Financial Statements, as concluded by FASB, are, at a minimum, to consist of:

1. Statement of Financial Position (Balance Sheet)

2. Income Statement

3. Statement of Comprehensive Income (SFAC No. 6)

4. Statement of Cash Flows

5. Statement of Owners Equity (Dyckman et al., 1989)

Generally Accepted Accounting Principles (GAAP)--are said to be rooted in "experience, reason, custom, usage, and practical necessity" (Wolk \& Teaney, 1997). GAAP "encompass the conventions, rules and procedures necessary to accepted accounting practice at a particular time” (Wolk \& Teaney, 1997).

Income Statements -- report the company's revenues, gain, expenses, losses, and net income (Dyckman et al., 1989). It also referred to as a Profit and Loss Statement. 
The International Accounting Standards Board assumed accounting standard-setting responsibilities from its predecessor body, the International Accounting Standards Committee, on April 1, 2001("International Accounting Standards Board About Us," 2008).

International Financial Reporting Statements -- defined by the IASB as the equivalent to the Statement of Financial Accounting Standards ("International Accounting Standards Board About Us," 2008)

Securities and Exchange Commission's (SEC) -- an independent regulatory agency of the government. Companies whose stock is traded on the stock exchanges are required to file annual audited reports and quarterly reports with the SEC. The responsibly of the SEC is to prescribe accounting policy and practices to be followed by companies traded publicly (Dyckman et al., 1989).

Statement of Financial Accounting Concept (SFAC) -- provides the fundamental doctrine on which financial accounting and reporting standards will be based (Dyckman et al., 1989).

Statement of Financial Accounting Standards (SFAS) -- establishes the accounting principles and procedures for a wealth of specific accounting issues (Dyckman et al., 1989).

\section{LITERATURE REVIEW}

The current standard setting system went through some evolution. The first standards board was the Committee on Accounting Procedure (CAP), which issued Accounting Research Bulletins (ARBs). This committee set forth what was believed to be GAAP, and the ARB were recommendations only. By the mid 1950 this committee became inactive, and in 1959, the establishment of the Accounting Principles Board (APB) was completed by the AICPA. The basic responsibility of the APB was to develop a statement of accounting concepts and issue pronouncements on current accounting issues through Accounting Principles Board Opinions. The lack of participation by organizations other than the AICPA, the failure of the APB to develop a statement of objective, and insufficient output all lead to the rise of the Financial Accounting Standards Board in 1973 (Dyckman et al., 1989).

The FASB is a private-sector body with seven full-time members whose mission is to "establish and improve standards of financial accounting and reporting for the guidance and education of the public, including issuers, auditors and users of financial information" ("Facts about FASB," 2006). The issuance of accounting standards is essential to the efficient functioning of the economy because decisions about the allocation of resources rely heavily on credible, concise, transparent and understandable financial information ("Facts About FASB," 2005). This financial information is used by the public in making numerous kinds of decisions.

The FASB develops accounting concepts and standards for financial reporting. The conceptual framework developed by the FASB sought to "develop an authoritative coherent structure of objectives and board fundamentals of financial accounting"(Pate \& Stanga, 1989). This conceptual framework starts with the objectives of financial reporting and leads logically to the best reporting of information to investors, creditors and all users of the financial statements (Pate \& Stanga, 1989). The six different statements of the conceptual framework are shown in Table 1:

Table 1

\begin{tabular}{|l|c|}
\hline \multicolumn{1}{|c|}{ Statement of Financial Accounting Concepts } & Date Published \\
\hline SFAC No. 1 Objectives of Financial Reporting by Business Enterprises & 1978 \\
\hline SFAC No 2 Qualitative Characteristics of Accounting Information & 1980 \\
\hline SFAC No 3 Elements of Financial Statements of Business Enterprises & 1980 \\
\hline SFAC No 4 Objectives of Financial Reporting by Non-business Organizations & 1980 \\
\hline SFAC No 5 Recognition and Measurement in Financial statements of Business Enterprises & 1984 \\
\hline SFAC No 6 Elements of Financial Statements (a replacement of SFAC No 3 and amending SFAC No 2) & 1985 \\
\hline
\end{tabular}

(Wolk \& Teaney, 1997). 
The FASB has also issued Statements of Financial Accounting Standards 1-156. These standards cover all areas of accounting, such as accounting changes, inventory, and the financial statements.

This conceptual framework provides the guide for standard setting. In order for our "capital markets to function effectively and for our economy to allocate resources efficiently, it is essential that business enterprises report accurately and fairly to investors and that investors perceive that they do so. Our economy needs both the fact and appearance of credible financial reporting" (Cook, 1987). This creditable financial reporting is derived from financial statements free of fraud, error and material misstatements. The previously mentioned items hinder the reliability of the financial reports.

By reviewing accounting history, one finds that the FASB was established in 1973 with the express objective to formulate a conceptual framework of accounting. The project came to completion in 1978 with the publication of its first SFAC 1- Objectives of Financial Reporting by Business Enterprises (Vorster, 2007). All the SFAC published to date, as mentioned earlier, comprises the entire Conceptual Framework by the FASB. In 1989, the then International Accounting Standards Committee (IASC) issued a statement entitled Framework for the preparation and presentation of financial statement, which in 2001 was formally adopted by the IASB (Vorster, 2007). The six major sections of this document are shown in Table 2:

Table 2

\begin{tabular}{|l|}
\hline \multicolumn{1}{|c|}{ Framework for the Preparation of Financial Statements } \\
\hline Objectives of Financial Statements \\
\hline Qualitative Characteristics of Financial Statements \\
\hline Elements of Financial Statements \\
\hline Recognition of the elements of financial statements \\
\hline Measurement of the elements of financial statements \\
\hline Concepts of Capital and Capital Maintenance \\
(Campell, Hermanson, \& McAllister, 2002)
\end{tabular}

(Campell, Hermanson, \& McAllister, 2002).

\section{FASB \& IASB Comparison of Elements of Financial Statements}

The FASB Conceptual Framework defines 10 elements of financial statements for business enterprise, while the IASB framework defines only five. Similarly, the FASB framework also defines investments by owners and distribution to owners as separate balance sheet element, whereas the IASB framework does not define separately. The definition of a liability requires future scarifies of economic benefits to be probable, which is not defined in the other frameworks under consideration in this study. The IASB conceptual framework states that a liability is an obligation with expected result in an outflow of economic benefit (Scott, 2002). The FASB identifies and defines five income statement elements for performance as: revenues, expenses, gains, losses and comprehensive income. The IASB only defines two elements as income which includes revenues and gains and expense which includes losses (Campell et al., 2002).

The FASB conceptual framework encourages that financial statements should provide decision useful information for financial statement users, that financial statement information should be relevant and reliable and the assets/liabilities involve future benefits/scarifies. SFAC 1 states that investors and creditors are among the most obvious prominent external groups who utilized the information provided by financial reporting. The IASB Framework for the Preparation and Presentation of Financial Statesman states that financial statements are directed toward common information needs for a wide range of users. Note these two regulatory bodies have broad and varied views on the use of financial reporting statements.

\section{METHODOLOGY}

This qualitative study analyzes the impact that the conceptual framework has on the financial statements by interviewing a $\mathrm{CFO}$ with experience in reviewing the publicly traded financial statement of companies with reporting entities in Canada and the United States. 
The Financial Accounting Standards Board (FASB) has been the designated organization since 1973, in the private sector for establishing standards of financial accounting and reporting ("Facts About FASB," 2005). The International Accounting Standards Board (IASB) has been the counterpart of the FASB in the global arena. The Canadian Institute of Chartered Accountants (CICA) accounting standards board (AcSB) is the regulatory body that is equivalent for Canadian companies.

The procedure used to conduct this research is to determine the impact in IASB and FASB conceptual framework by interviewing a CFO with experience in IASB International Financial Reporting Standards (IFRS) used by Canadian publicly traded companies as compared to the United States. One of the outcomes of this study is to analyze the influence that the conceptual framework of both regulatory bodies has on the financial statements.

The data is gathered by reviewing and analyzing the interview of the CFO by conversations, observations, documents, financial statements, and interviews.

\section{Locating Site/Individual}

This is the first step of the process. In this case study one interview will be conducted and analyzed to note the impact that the conceptual framework has on the financial statements. This individual was selected for his experience with financial statements prepared in Canada according to IASB conceptual framework and those financial statements prepared in the United States under the framework of the FASB.

\section{Purposefully Sampling}

The selected countries were chosen for their distinct financial reporting standards. Canada adopts the IASB as the regulatory body; conversely the United States adopts SFAC under the regulatory jurisdiction of FASB. The interviewer is a Chartered accountant in Canada and has worked for Deloitte and Touché for many years. He is currently the Chief Financial Officer for a privately held real estate investment company in the United States. He has experience with the preparation of financial statements in the above-mentioned countries.

\section{Data Collection}

The interview was conducted in the office and was audio tape recorded. It was structured around five open-ended questions with the reserved right to expand upon responses. Below is a brief description of the interview process:

Question 1: What impact does the conceptual framework have on the FS?

Answer: From a practical standpoint I believe that the new conceptual framework is a step in the right direction in simplifying the reporting of international conglomerates that report in multiple public markets. Benefits include:

1. reduced costs of compliance

2. reduced "translations" of corporate results for multiple markets

3. less confusion for users

I believe the implementation of the Conceptual framework will require that users interpreting financial results be more sophisticated - principles are subject to more interpretation and therefore require more knowledge to properly interpret.

In its simplest form, the same company could report significantly different results in different markets if it is forced to follow a "rules" based approach to reporting (a framework similar to that adopted by FASB). The rules will drive the disclosure. If you assume that markets are efficient then as long as a transaction is disclosed the market will properly interpret the information it receives regardless of the rule applied to its disclosure. By way of example, if a company has losses to carry forward to apply to reduce a future taxable income steam whether those losses are capitalized or not (FASB sets out specific rules). The determination on whether to capitalize in a principle 
based environment will be based on a more general - potential future benefit requirement. There could be a reasonable future benefit judgment that would allow for the recording of the asset however, strict adherence to the FASB rule may prevent capitalization. Regardless of the method of disclosure the market will/should properly evaluate the true "value" of the asset.

Question 2: What would a global conceptual framework do to the FS?

Answer: I believe that the global conceptual framework will have the same benefit internationally that a more principle based reporting framework would have domestically in the US (reduced costs of reporting, fewer compliance costs - same transaction recorded the same way across multiple markets)

Question 3: Would one framework improve financial reporting?

Answer: Yes. The challenge with a rules based system for reporting that it is not flexible enough to deal with the complexity of financial transactions evolving at a rapid rate. Companies are forced to a principle-based system (to look to a more conceptual framework) if there are no specific 'rules' for the recording of a particular transaction.

Readers of financial reports would not be forced to deal with the mixed signals suggested by the different reporting of the same transaction in different markets.

Question 4: Should the FASB be more principles-based as opposed to the current rules-based approach?

Answer: Yes.

Question 5: What would be your recommendation to improve the conceptual framework, if any?

Answer: I believe that the framework has to address the reporting of the fair market value of transactions and the transition of current models adopted by domestic standard setting boards to the new model.

\section{RESULT}

The results from this study include an interview with a CFO to determine his evaluation of the impact the conceptual framework has on the financial statements. His experience in analysis of financial statement of companies reporting in Canada and the United States provided insight into the IASB and FASB conceptual framework. An additional finding of reviewing the conceptual framework is that the FASB states historical cost as the basis for recording financial instruments as opposed to the IASB using fair value as the cost basis for recording the transaction. In March of 2007 the SEC proposed amendments to Form 20-F, Registration of Securities of Foreign Private Issuers that would affect such entities adopting IFRS (Gannon\& Ashwal, 2007). The proposals' purpose is to ease the burdens of foreign companies will face when they adopt IFRS for the first time, to improve their financial disclosure to investors and to encourage other foreign companies to voluntarily adopt IFRS (Gannon\& Ashwal, 2007).

CPAs and accountants should use care when reviewing financial statements to ensure that they gain an understanding of the financial statements upon review. The global conceptual framework will make the review of financials across countries and industries more congruent and consistent.

\section{SUMMARY AND CONCLUSION}

In conclusion, this paper presented a proposal for research on the impact that the conceptual framework has following the qualitative research method of the case study with the case being bound by one interview of the Chief Financial Officer of a company with experience in public traded financial statements and being a charted accountant in Canada. The themes identified and learned were based on the interviewee comments that a global conceptual framework would be beneficial to organizations. Reduction of costs and less confusion were represented as strengths in adopting a global framework. 
Future research could be completed by interviewing other parties in similar roles. Individuals in Chief Accounting Officer roles, SEC Managers, and Directors of Accounting roles can be interviewed, especially if the companies they work with are multinational organizations.

\section{AUTHOR INFORMATION}

Veronica Paz is a doctoral student at the H. Wayne Huizenga School of Business and Entrepreneurship at Nova Southeastern University and a Corporate Controller in private industry. Veronica has worked for such companies as AutoNation, Arthur Andersen and several manufacturing firms.

Dr. Thomas Griffin is Professor of Decision Sciences at the H. Wayne Huizenga School of Business and Entrepreneurship at Nova Southeastern University. He teaches master lever and doctoral level courses including strategy, statistics, operation management and finance.

\section{REFERENCES}

1. AICPA Mission: The Fundamental Purpose. (2008). Retrieved April 1, 2008, 2008, from http://www.aicpa.org/About+the+AICPA/AICPA+Mission/

2. $\quad$ Campell, J. E., Hermanson, H. M., \& McAllister, J. P. (2002). Obstacles to International Accounting Standards Convergence. The CPA Journal, 72(5), 20-24.

3. Cook, J. M. (1987). Special Report: Progress in Financial Accounting Since February 1985. The CPA Journal, 5(57), 4-24.

4. Creswell, J. W. (2007). Qualitative Inquiry and Research Design: Choosing among Five Traditions. (Second ed.). Thousand Oaks, CA: Sage Publications.

5. Dyckman, T. R., Dukes, R. E., \& Davis, C. J. (1989). Intermediate Accounting (Third ed.). Chicago: Irwin Press.

6. $\quad$ Facts About FASB. (2005).

7. Facts about FASB. (2006). Retrieved May 10, 2006, from http://www.fasb.org

8. International Accounting Standards Board About Us. (2008). Retrieved April 1, 2008, 2008, from http://www.iasb.org/About+Us/International+Accounting+Standards+Board+-+About+Us.htm

9. Pate, G. R., \& Stanga, K. G. (1989). A Guide to the FASB Concepts Statements. Journal of Accountancy, $168(2), 28$.

10. Scott, W. R. (2002). An International Comparison and Evaluation of Financial Accounting Concept Statements. Canadian Accounting Perspectives, 1(2), 163.

11. Vorster, Q. (2007). The Conceptual Framework, Accounting Principles and what we believe is true. Accountancy SA, 30-33.

12. Wolk, H. I., \& Teaney, M. G. (1997). Accounting Theory (Fourth ed.). Cincinnati: South-Western College Publishing.

13. Young, D. W. (1994). Introduction to Financial \& Management Accounting a User Perspective. Cincinnati: South-Western College Publishing. 
NOTES 